\title{
Energy-saving problems of road facilities in Russia
}

\author{
Y. V. Trofimenko ${ }^{1}$, G. I. Evgenev ${ }^{2} \&$ T. Y. Grigoreva ${ }^{1}$ \\ ${ }^{I}$ Energy-ecological Department of Moscow Automobile and \\ Road Technical University (MADI), Russia \\ ${ }^{2}$ Ministry of Transportation of the Russian Federation, Russia
}

\begin{abstract}
The total length of federal highways in Russia is $50,749.2 \mathrm{~km}$, which is only $5 \%$ of all the roads of the country, but they form the basic road network of Russia's two-thirds road freight turnover. Nearly $80 \%$ of these roads are overloaded, which leads to intensive destruction of the roads, and, hence, the apparent increase of vehicle fuel consumption and energy demand related to roadway maintenance works, traffic safety and users' comfort. The work purpose is a scientific substantiation of actions needed to improve energy efficiency of Russian road facilities up to the level of advanced countries of the world.

The authors have developed the methodology to allow the quantitative determination of increasing energy efficiency for the public road system in the following basic directions: substantiation of design choices based on a minimization of energy costs during the whole life cycle of a road; normalization of energy consumption of the manufacturers producing road-building materials; use of the best accessible energy-saving technologies and replacement of power inputs from nonrenewable resources by renewable, which are related to traffic safety, users' comfort; development of recycling technologies for energycontaining waste, for example, mill culls and brush wood; adaptation of "green standards" of the real estate objects (LEED, BREEM) for linear road constructions, primarily, the object of road service. The results of statistical, settlement and experimental research which are useful both for scientific purposes and also represent a practical interest for the investors involved in the realization of mechanisms of public-private partnership in design, construction and maintenance of roads are represented in this paper.
\end{abstract}

Keywords: Russian road facilities, energy efficiency, green standards, energysaving technologies. 


\section{Introduction}

The total network length of public roads in Russia is $1.1 \mathrm{mil} . \mathrm{km}$, which includes $300,000 \mathrm{~km}$ of roads with improved capital pavement type and $50,750 \mathrm{~km}$ of federal highways. Federal highways form the basis of the Russian road network. However, the road network is not formed yet; at least $200,000 \mathrm{~km}$ of new roads need to be built, reconstructing not less than $80 \%$ of the federal roads network. Most of motorways are already congested. At the same time, high road maintenance level, irrespective of the natural environment and climatic factors should be guaranteed. Thus, construction, reconstruction, operation, maintenance and repair works need significant energy and material resources (Lukanin and Trofimenko [1], Trofimenko and Evgenev [2], Trofimenko and Grakovich [3]).

The purpose of work is for a substantiation of measures which should be taken to increase the energy efficiency of Russian public roads up to the level of advanced countries.

The specific aspect of energy-saving works in the Russian road sector, unlike the countries in Western Europe, is that there is a need to consider the nonuniform density of the road network and a large number of climatic zones (from tundra and permafrost, to subtropics). Guided by these factors, the Russian transport system could be divided into three subsystems; each one having its own development and power supply priorities.

1. The transport subsystem of the European part of Russia has a developed road infrastructure, which carries the main cargo traffic. The road network in this area is a testing area for the implementation of large-scale infrastructure projects, related to the development of public-private partnerships (toll roads) mechanisms, implementation of modern "green" technologies for road construction and maintenance. Here, there is the construction of a $650 \mathrm{~km}$ highspeed toll motorway Moscow-St. Petersburg (SPAD) and construction of the Central Ring Road, with future operation on a toll basis (TSKAD), allowing transit traffic to bypass the Moscow agglomeration. These motorways will provide an access from the Baltic Sea to Turkey and through Kazakhstan to China.

\section{Case study 1: energy expenditures for asphalt concrete materials transportation and transport subsystems of the European part of Russia}

Energy-efficient technical solutions related to the construction and repair works of asphalt concrete roads in each specific area should be based on the comparative assessment of the material, energy and financial resources cost.

It is known, that the energy expenditures for the construction of asphalt concrete pavements are equal to the sum of expenses for the production of raw materials and the transportation of these materials to the mixing plant, preliminary treatments and manufacturing of asphalt mixes, than transportation of the mix to the construction site, laying and compacting of the ready mix 
(Lukanin and Trofimenko [1], Rudenskij [4]). At the same time, 25-45\% of total energy expenditures are spent on the production of road-building materials, their preliminary treatment and transportation to the construction site. Table 1 shows the estimation of the specific volume of road-building materials required during the road construction in Russia. It should be mentioned that road types are different. Thus, the magnitude of energy is determined by Rudenskij [4].

Table 1: Pavement construction: specific volumes of road-building material consumption; $\mathrm{t} / \mathrm{km}$ of the road.

\begin{tabular}{|c|c|c|c|c|c|c|}
\hline \multirow[t]{2}{*}{ Road type } & \multirow{2}{*}{$\begin{array}{l}\text { Pavement } \\
\text { width, m }\end{array}$} & \multirow{2}{*}{$\begin{array}{l}\text { Pavement } \\
\text { thickness, } \\
\mathrm{cm}\end{array}$} & \multicolumn{4}{|c|}{ Volume of materials consumption } \\
\hline & & & $\begin{array}{l}\text { Crushed } \\
\text { stone }\end{array}$ & Sand & $\begin{array}{l}\text { Mineral } \\
\text { powder }\end{array}$ & Bitumen \\
\hline $\begin{array}{l}\text { Two-lanes } \\
\text { secondary } \\
\text { road }\end{array}$ & 7 & 10 & 850 & 580 & 130 & 90 \\
\hline $\begin{array}{l}\text { Multilane } \\
\text { motorway }\end{array}$ & 21 & 18 & 4600 & 3200 & 700 & 500 \\
\hline
\end{tabular}

Due to the calculations, it was found that for the manufacturing of materials needed for $1 \mathrm{~km}$ of the secondary road with asphalt pavement it is necessary to spend $125 \mathrm{GJ}$ of energy. And for the manufacturing of materials for $1 \mathrm{~km}$ of motorway with asphalt pavement nearly 5.5 times more energy (680 GJ) is needed to be spent.

Energy expenditure which is needed for transportation of the crushed stone, sand, mineral powder and bitumen to the mixing plant depend on the distance and way of material conveyance. It is a well known fact that not every stone can be used in the asphalt mix. There is a lack of stone deposits in central Russia. Stone material is delivered by railroads from Karelia, Urals Mountains, Belarus and Ukraine at a distance of hundreds or thousands of kilometers (Fig. 1). For the construction of asphalt layer with a thickness of about $10 \mathrm{~cm}, 500-1000$ tons of crushed stone material are needed.

Transportation and material handling operations (estimated length of haul is $1500 \mathrm{~km}$ ), requires 100-200 GJ of energy expenditure. While transportation of the same amount of local stone or sand materials by trucks (at an average distance of $35 \mathrm{~km}$ ), taking into account the energy expenditure for loadingunloading, requires 6 times less energy (19.6-34.6 GJ). Transportation of 100120 tons of bitumen ( 2 tanks) by railroad requires nearly 17-20 GJ of energy and transportation of 65-200 tons of mineral powder - 20-35 GJ.

Using imported stone material, the energy cost of transportation of materials needed for the pavement construction $1 \mathrm{~km}$ in length will be 180-300 GJ and 120-150 GJ using local materials. In total, the energy consumption for the construction of the asphalt pavement layer if $10 \mathrm{~cm}$ thickness and $1 \mathrm{~km}$ length is 800-1200 GJ. Specific energy consumption per $1 \mathrm{~m}^{2}$ of asphalt pavement is $0.125-0.170 \mathrm{GJ}$ (at an average of $0.15 \mathrm{GJ}$ ). 


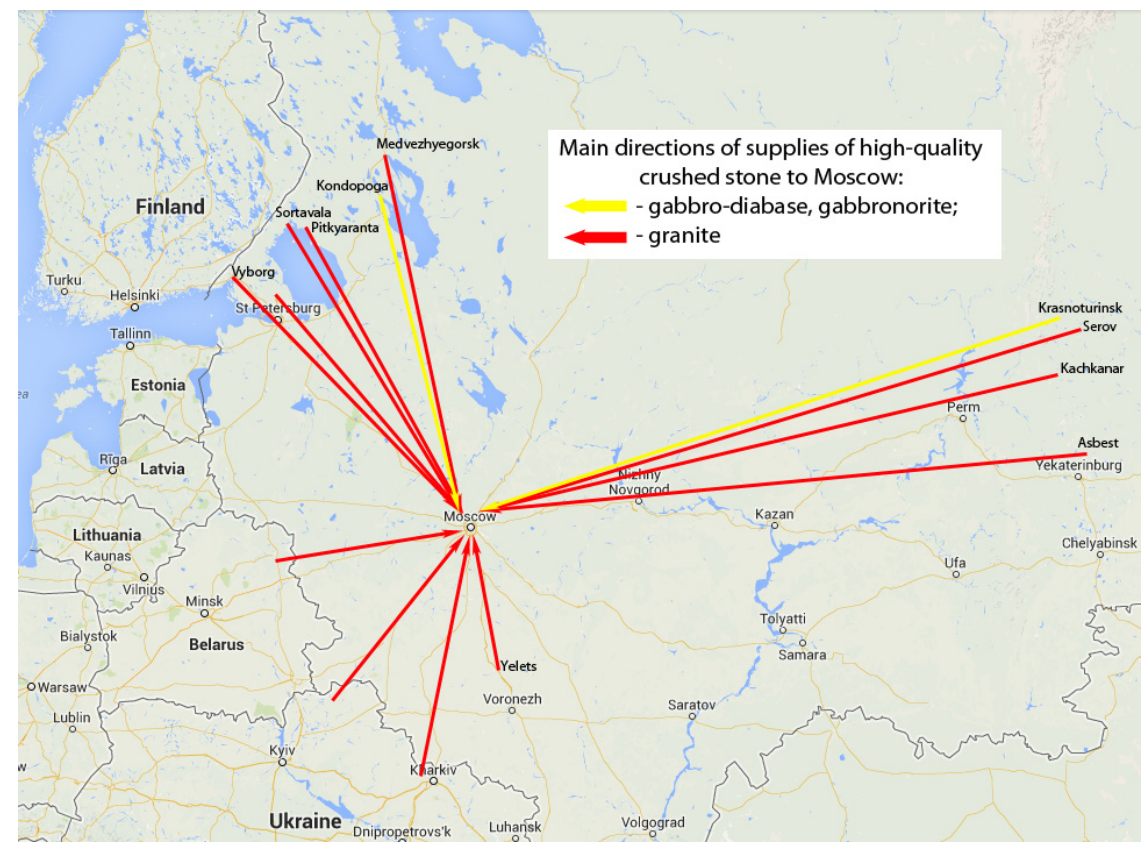

Figure 1: Distance of stone materials transportation.

As a result, the part of energy consumption for transportation activities (including loading and unloading) is $25-30 \%$ of the total energy consumption for asphalt paving, including direct transportation of the manufactured hot mix to the construction site, which is $10-15 \%$.

Let us consider energy efficiency of such measures as the increase of pavement durability and the usage of local materials.

Increasing the pavement life-cycle is one of the most effective methods of energy- and resource-saving.

If it is required to increase the smoothness and road adhesion of dual lane roads $1 \mathrm{~km}$ length, nearly 200 tones of asphalt mix are needed (at an average of once every 3-4 years, according to current specifications of a time-period between overhauls). To repair all over the asphalt roads 20 mil. tones of the mix are needed.

Implementation of innovative technical solutions may help to double the lifetime of a pavement, which will save 12-14 mil. tones of crushed stone, up to $11 \mathrm{mil}$. tones of sand, $3.5 \mathrm{mil}$. tones of mineral powder and $1.5 \mathrm{mil}$. tones of bitumen.

Due to the implementation of modern technologies, it is possible to replace $25 \%$ of high-strength imported aggregate by local materials (without any loss in the quality of the asphalt mix). In such way there is a possibility of reducing energy consumption for transportation of up to $20 \mathrm{GJ}$ per $1 \mathrm{~km}$ of pavement. 


\section{Case study 2: calculation of energy consumption for the existing motorway M-10 Moscow-St. Petersburg and the new high-speed motorway M-11}

Based on the traffic forecasts, the energy demand for both motorways for 2030 was predicted. The traffic forecast for the existing M10 "Moscow-St. Petersburg" and the new M11 "SPAD" was performed using the program complex SATURN. It was considered that the maintenance level of the M10 will be kept at the same level as nowadays and the M11 will be constructed with the implementation of modern technologies and technical innovations in the energysaving area.

As a result of the calculations, it was found that if the traffic from the M10 were transferred to the M11 (on the section from Moscow to St. Petersburg) it would be possible to cut down the energy expenditure by 30-35\%. A traffic growth rate on all sections ( 21 in total) in the year 2030 was considered to be the same as in 2010. Such saving levels could be reached by improving the pavement quality, using light emitted diodes in the highway lighting system, the utilization of biomass, for example - felling waste producing liquid fuel, implementation of "green standards" and application of environmental management systems (ISO 14000).

2. For the development and economical growth of the Volga region, Southern Urals and Southern Siberia, supporting an advancing extension of the road network is strongly needed. International transit traffic will increase correspondingly to the network extension.

3. The transport subsystem of the north of Siberia and the Far East differ from other regions by low density and connectivity of the road network. There is a permafrost soil and sharply continental climate and the difference between maximum summer temperature and minimum winter temperature reaches 100 degrees (from $+50^{\circ} \mathrm{C}$ to $-50^{\circ} \mathrm{C}$ ). With the exception of several federal motorways, year-round transportation is possible only by aircraft. The main cargo traffic is carried out by "winter snow road". Winter roads run through the river and bog beds; non wooded areas. Roads like these exist only during the winter period - from November till April.

\section{Case study 3: diversification of energy sources and perspectives of the energy consumption reduction during the construction and operation of the federal motorway A-331 "Vilyui" from Tulun (Irkutsk region) to Yakutsk}

In recent years, the transport infrastructure of the Far East is developing. As an example, the construction of federal road A-331 "Vilyuy" was considered. Construction works were started in 2013. Figure 2 shows the variants of construction. 


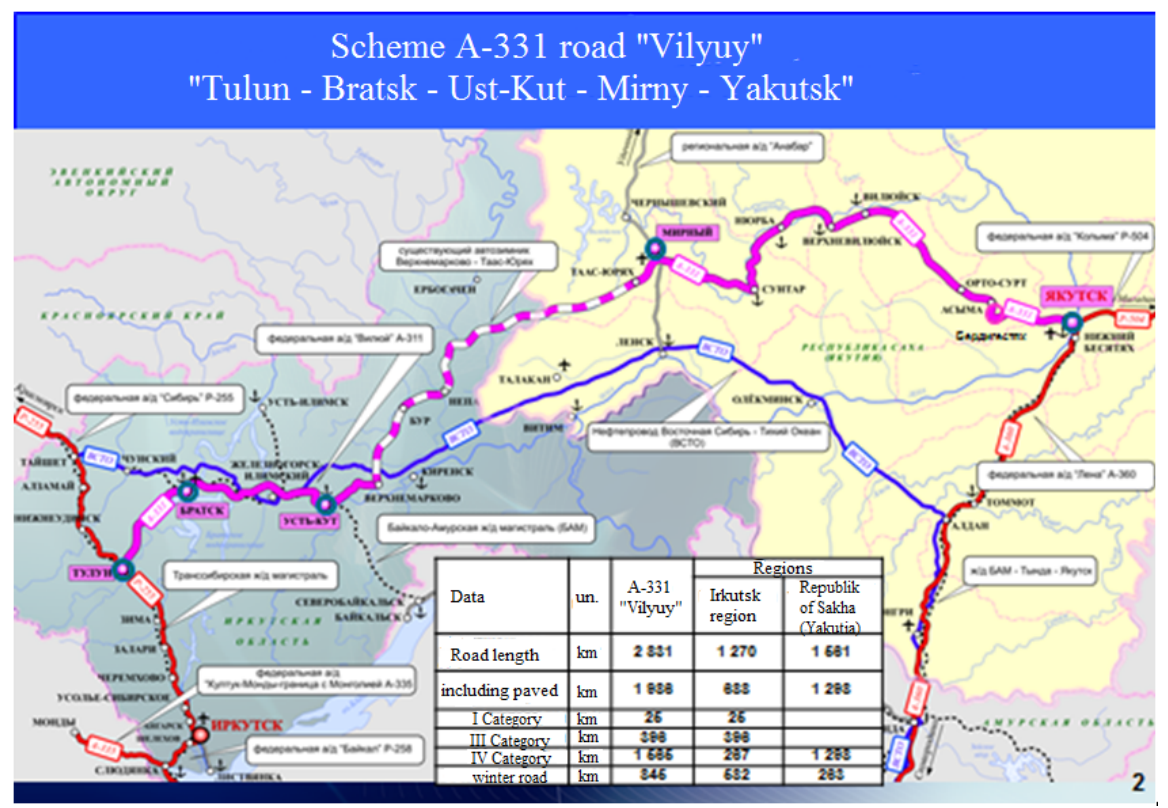

Figure 2: Variants of the "Vilyuy" road layout. (Dash line - the existing winter road 846 km length.)

After a comparison, the "northern" route (purple line) was chosen. The road is $806 \mathrm{~km}$ in length. For the road construction, nearly 600 hectares of forest needs to be cut down. The earthworks volume is $52,200 \mathrm{~m}^{3}$, due to the project, 5 big and 59 small bridges should be constructed and 7.7 mil. $\mathrm{m}^{2}$ of asphalt pavement should be laid out. This variant was selected due to the presence of the winter road. The winter road could be used from November till April, meaning that earthworks could be done during this period. Fewer service roads will be needed, and correspondingly less energy will be spent. In comparison with other variants, the construction period could be reduced by more than 1 year. Mirny city is a diamantiferous province of the Yakutia region. The accepted variant of the road is the shortest link from Mirny to the Irkutsk region.

Construction camps, roadside service facilities and small population centers should be supplied with electricity during the construction stage as well as during the operation stage. Traditional power supply solutions could not be implemented here because of the high cost of long-distance transmission circuit laying; substations and other power infrastructure. Energy to every site is supposed to be provided along the motorway by applying the renewable sources. The most common are: combined solar-wind power stations (in South Yakutia where there are 230 sunny days per year), gas generators using the local fuel (wood waste) and standby diesel generators. This decision was made by the Russian Government in 2013 as a part of the State program "Socio-economic development of the Far East and the Baikal region till 2025". 

to:

In the energy-poor zones, bordered with the designed motorway, it is assumed

- replace ineffective sources of heat and electrical energy by effective miniTTP with a total efficiency of not less than $90 \%$;

- utilize local fuels in order to reduce the imported fuel segment;

- utilize renewable energy sources (wind-power station (WPS), solar power system (SPS), small hydroelectric power stations, power stations on felling waste, etc.) and integrated solutions (wind-diesel and other hybrid power stations); the main idea of such actions is environmental protection and reduction of fuel consumption;

- implement eco-technologies and environmental protection measures on the objects of electric power industry.

It is assumed that research programs in the field of wind and solar power systems development will be realized. Government databases including information about potential of wind and solar energy, mini- and micro- hydroelectric power stations, biomass and other local renewable resources should be kept up-to-date. Biomass and other local renewable resources should be implemented as often as possible. In that way, a significant part of diesel energy could be replaced. Hence, the transportation cost savings.

The mechanisms of public-private partnership (PPP) works also on the projects of road construction in Siberia and the Far East regions, including energy poor zones. And there are some specific points:

1. The necessary investment amount could not be reached only by inclusion of private investments, because:

- $\quad$ projects in the electrical energy industry could be economically inefficient. As the majority of such projects are initially socially oriented (in particular, they could be characterized by the negative net present value for the private investor);

- the investments' amount and time horizons of the projects' realization could not meet the requirements of private investors.

Along with low potential efficiency for private investors, the planned activities are highly effective for the society and nation state. The level of crosssubsidization will be reduced, new vacancies will be created and the level of tax payments to budgets of all levels will be significantly increased - these are the society and nation state benefits. An effect of technological, legal, financial, economic, human and environmental risks should be forecast before the realization of the local power station projects. A system of avoidance of negative effects should also be formed.

The results of statistical, analytical and experimental research regarding energy-saving issues in the Russian public road system have both commercial and scientific interest.

Nowadays, the government works together with private companies in order to improve a public service such as a road system; doubtless the energy-saving key will be useful for both parties. 


\section{Conclusions}

In this paper, concrete examples of the main directions of energy- and resourcesaving programs in Russian transport segment are considered. These directions are connected with:

- $\quad$ substantiation of design decisions based on the minimization of energy demand during the whole life cycle of a road; adaptation of "green standards" of the real estate objects (LEED, BREEM) for linear road facilities, primarily, the objects of road service; and application of environmental management systems according to ISO 14000 standards;

- $\quad$ rationing of energy consumption at the aggregate and binder plants;

- use of the best available technologies for energy saving and substitution of non-renewable energy sources by renewable ones;

- development of recycling technologies for energy-containing waste, such as cull lumber and felling waste producing liquid fuel.

\section{References}

[1] Lukanin, V.N. \& Trofimenko, Y.V., Optimization of reserve maintenance periods by criterion of total power inputs. Science and techniques in road sector, 4 (7), pp. 1-7, 1998.

[2] Trofimenko, Y.V. \& Evgenev, G.I., Ecology: transport infrastructure facility and an environment, M.: the Publishing center "Academy", 400 p., 2008.

[3] Trofimenko, Y.V. \& Grakovich, V.F., About conformity of normative and methodical base to modern environmental requirements at construction and operation of highways in Russia. Safety in a technosphere, 2, pp. 59-64, 2012.

[4] Rudenskij, A.V., Resource-saving during construction by the example of road field. Scientifically-practical magazine "Modernization. Innovation. Development", 3 (7), pp. 4-8, 2011. 